\title{
EMERALDS FROM THE MANANJARY REGION, MADAGASCAR: INTERNAL FEATURES
}

By Dietmar Schwarz

Inclusions in emeralds from the Mananjary region in the eastern part of the island nation of Madagascar are reported and compared with inclusions in emeralds from other, especially African, localities. Although most of these internal features are similar to those found in emeralds from other schist-type deposits, Mananjary emeralds usually can be separated from emeralds from other localities by means of associations of certain mineral inclusions (especially talc, carbonates, amphiboles, and quartz) with specific types of fluid inclusions.

\section{ABOUT THE AUTHORS}

Dr. Schwarz is a research gemologist with the Gübelin Gemmological Laboratory, Lucerne, Switzerland.

Acknowledgments: E. J. Petsch of Julius Petsch Jr., G. Becker of Friedrich August Becker, D. Th. Klein of Fritz Klein, K. Heringer of Kempfeld, $L$. Haag, and Stefan Kehl-all of Idar-Oberstein, Germany-provided samples, as did Dr. H. A. Hänni of SSEF, Zurich, Switzerkand. Mr. Petsch, Mr. Haag, and Dr. Th. Eidt provided valuable information about Madagascar emeralds. J. I. Koivula of GIA, and G. Bosshart and C. Smith-both of the Gübelin lab-helped edit the original manuscript. Bettina Becker and Joachim Zang of the Department of Gemstone Research, Johannes Gutenberg University, Mainz, did some of the SEM and microprobe analyses. This study was part of a research project sponsored by the German Research Association (DFG) and carried out at the Johannes Gutenberg University of Mainz, Germany. All photomicrographs are by the author.

Gems \& Gemology, Vol. 30, No. 2, pp. 88-101

(C) 1994 Gemological Institute of America

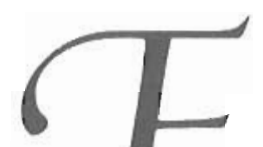

or many years, Africa has been one of the main producers of emeralds, with known schist-type deposits in Zambia, Zimbabwe, Mozambique, Tanzania, Egypt, and South Africa, as well as deposits formed in a special environment in central Nigeria. Significant quantities of fine emeralds (figure 1) have also been found in schists in the Mananjary region of Madagascar, a large island nation off the southeast coast of Africa (Schwarz and Henn, 1992). Until now, however, there has been little information in the gemological literature about the Mananjary emeralds and how their internal features compare with those of emeralds from schist-type deposits elsewhere.

According to knowledgeable sources (E. J. Petsch, Th. Eidt, W. Spattenstein, and H. Hänni, pers. comms., 1993), the Mananjary region was the only emerald-producing area in Madagascar until about two years ago, when mining began at a small deposit discovered in the southern region of Madagascar near the town of Benenitra (about $150 \mathrm{~km}$ east of the city of Toliara; see figure 2). However, this new deposit produces only small, dark crystals (E. J. Petsch, H. Hänni, and G. Spagnoli, pers. comms., 1993) and is not discussed further in this article.

The Mananjary region represents a mining area of considerable potential and size. Important mines within this region include an unnamed alluvial emerald occurrence, about $50 \mathrm{~km}$ west-southwest of Mananjary, near the town of Ifanadiana (Sinkankas, 1981); the Ankadilalana mine, near the town of Kianjavato (Hänni and Klein, 1982); and the Morafeno mine, about $30 \mathrm{~km}$ south of Mananjary (Schwarz and Henn, 1992). There are actually numerous operations throughout the region. In the general area of the Morafeno mine, for example, Thomas (1993) reports visiting nine mines: Ambodirofia, Ambodibonary, Ambadamanino, Ambodibakoly, Mororano, Ambodifandrika, Mohotsana II, Ambilanifitorana, and Ambodizainana. 
Figure 1. Large quantities of emeralds have been mined from deposits in the Mananjary area of Madagascar. These eight faceted Mananjary stones rangefrom 0.17 to $2.57 \mathrm{ct}$; the specimen measures approximately $35 \times 20 \times$ $15 \mathrm{~mm}$. Stones courtesy of H. Hänni and John $M$.

Bachman Inc.; photo (C) Harold e) Erica Van Pelt.

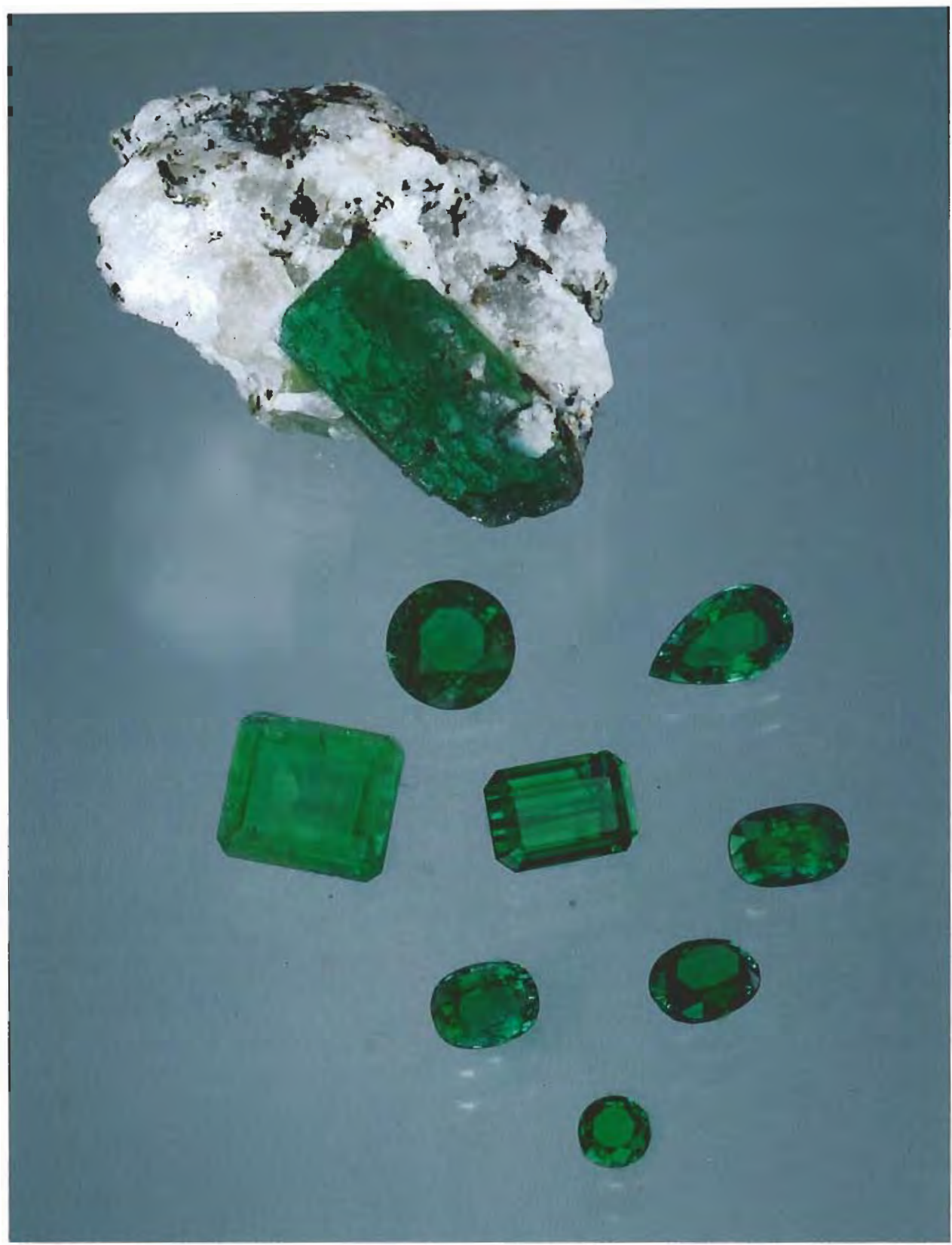

The present article provides the first comprehensive description of the inclusion features of emeralds from the Mananjary region. It also compares these internal characteristics to those observed in emeralds from other localities. In many cases, these Madagascar emeralds can be distinguished from emeralds from other occurrences on the basis of their inclusions.

\section{BACKGROUND}

Emerald Occurrences in Madagascar. Beryl is one of the most important of the more than 50 gem minerals found on Madagascar (Chikayama, 1989). Aquamarine and other beryls from Madagascar have been known in Europe since French occupation of the island in 1883. Levat (1912) appears to have been the first to mention an occurrence of emerald in Madagascar; Lacroix (1922) provided the first detailed survey account of occurrences-both primary and secondary (i.e., alluvial) - of gem-quality beryl there. However, the primary emerald occurrences that are in the vicinity of the coastal town of Mananjary have been known for only about 20 years. Sinkankas (1981) mentioned an emerald occurrence about $50 \mathrm{~km}$ west-southwest of Mananjary and about $250 \mathrm{~km}$ southeast of Tananarive (now named Antananarivo), the capital of Madagascar, near the town of Ifanadiana (again, see figure 2). In this alluvial deposit, small rounded emerald fragments have been found together with kyanite.

Hänni and Klein (1982) described emeralds from the Ankadilalana mine, near the town of Kianjavato. They reported that these emeralds, 


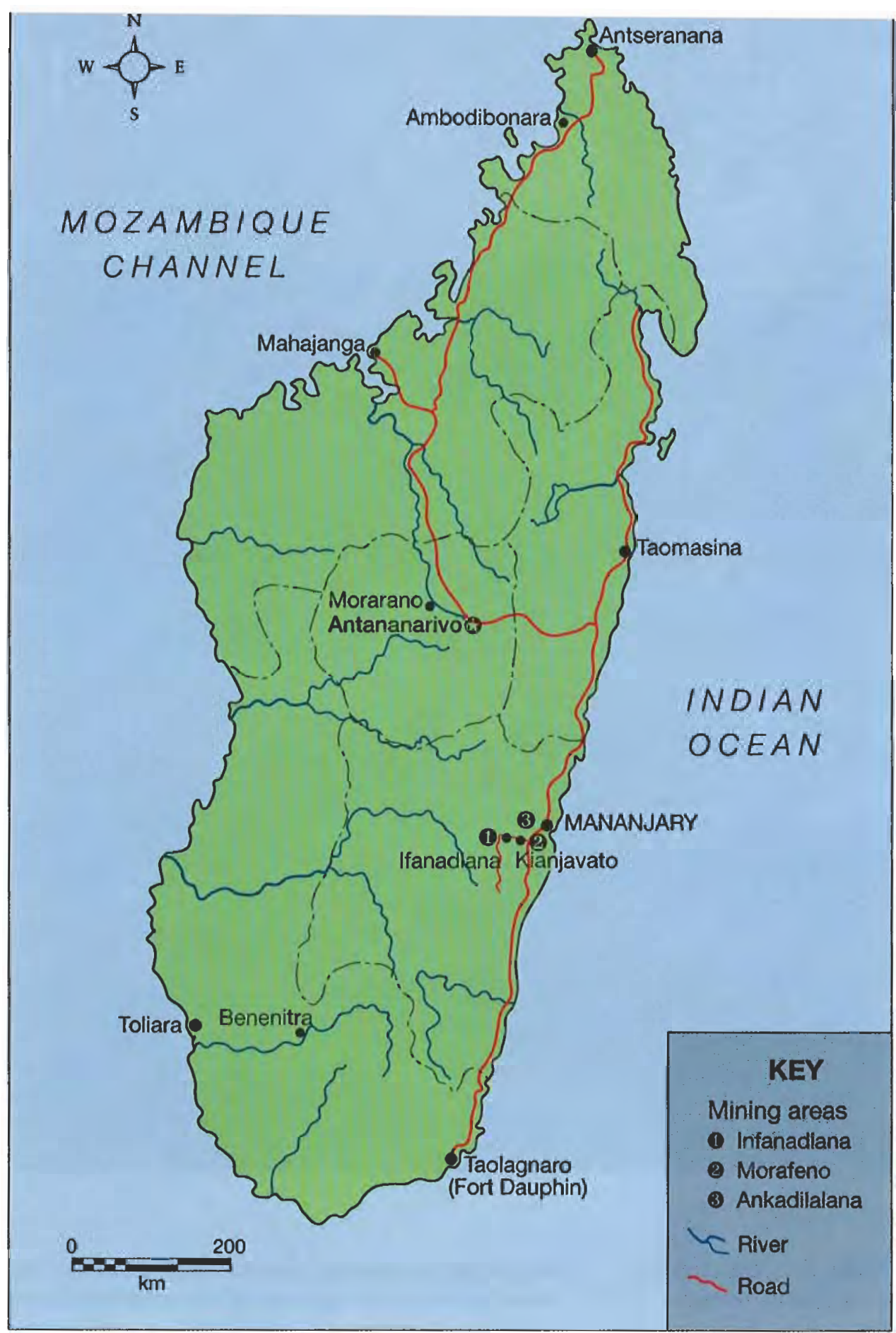

Figure 2. Several emerald deposits have been identified on the island nation of Madagascar, which lies off the southeast coast of Africa. With the exception of the recent discovery at Benenitra, most lie within $50 \mathrm{~km}$ of the city of Mananjary. Mining operations include the deposit near Ifanadiana, the Ankadilalana mine, and the Morafeno mining region.

which originate from a mica schist, are similar to Zambian emeralds with respect to their blue-green color and optical properties. They described the emerald mining at that time as sporadic and carried out with primitive equipment.

Only during the last few years have the Morafeno occurrences, about $30 \mathrm{~km}$ southeast of the Ankadilalana deposit, been exploited commercially (figure 3 ). These deposits, which are also embedded in mica schists and subordinately in amphibole schists, are considered extensive and rich in emerald mineralization (Th. Eidt, pers. comm., 1993). At the beginning of the 1990s, the worked area around Mananjary comprised at least $50 \mathrm{~km}^{2}$ (E. J. Petsch, pers. comm., 1993; Thomas, 1993). Mining is performed by independent miners and a number of small mechanized operations (figure 4). Precise figures for the quantity or value of emeralds produced to date are not available; most crystals range from one to three carats, but lowquality crystals up to 1,000 grams have been reported (E. J. Petsch, pers. comm., 1993).

Compared to emeralds from the African mainland, many of the stones from the Mananjary region are somewhat light in color; others are a bluer green, similar to Zambian emeralds lagain, see fig- 


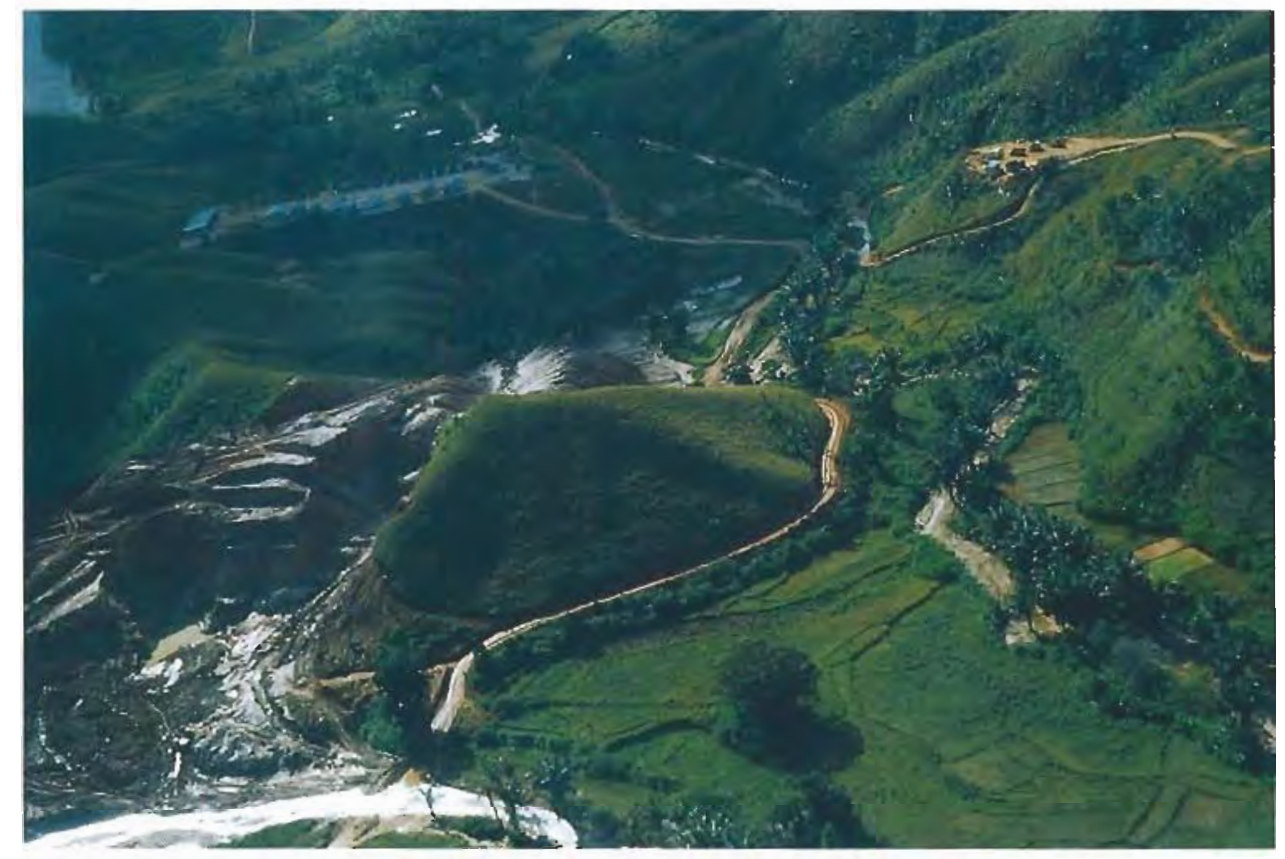

Figure 3. As this overview of one mining operation shows, some deposits in the Morafeno region have been worked extensively in recent years. Photo by E. Julius Petsch, of Julius Petsch Ir., Idar-Oberstein.

ure 1). The crystals range from opaque to transparent, and nice cabochons can be cut from translucent rough (figure 5). Generally, the emerald crystals are found embedded in the host mica or amphibole schist or in quartz (figure 6). Additional information on this locality, the material produced, and the gemological properties of these emeralds (which overlap those of $\mathrm{Fe}$ - and $\mathrm{Cr}$-rich emeralds from other schist-type deposits) can be found in Schwarz and Henn (1992).

Previous Inclusion Studies. To date, the following mineral inclusions (see table $\mathrm{I}$ ) and other internal features have been reported for emeralds from Madagascar. In the stones from Ankadilalana, Hänni and Klein (1982) identified brown biotite, muscovite, apatite, hematite, goethite, quartz, ilmenite, tourmaline, liquid/gas two-phase inclusions, and color zoning. Campbell (1991) observed goethite and hematite, as well as limonite and phlogopite, in a cabochon-cut emerald from Madagascar that also showed color zoning and negative crystals. M. L. Delé-Lasir and J. P. Poirot (pers. comm., 1991) identified the following mineral inclusions in emeralds from Madagascar by means of Raman spectroscopy: carbonates (ankerite), quartz, phlogopite, apatite, flu-

Figure 4. At Morafeno, this mining company uses a backhoe to reach the emeraldbearing schists. Photo by E. Julius Petsch, of Julius Petsch Jr., Idar-Oberstein.

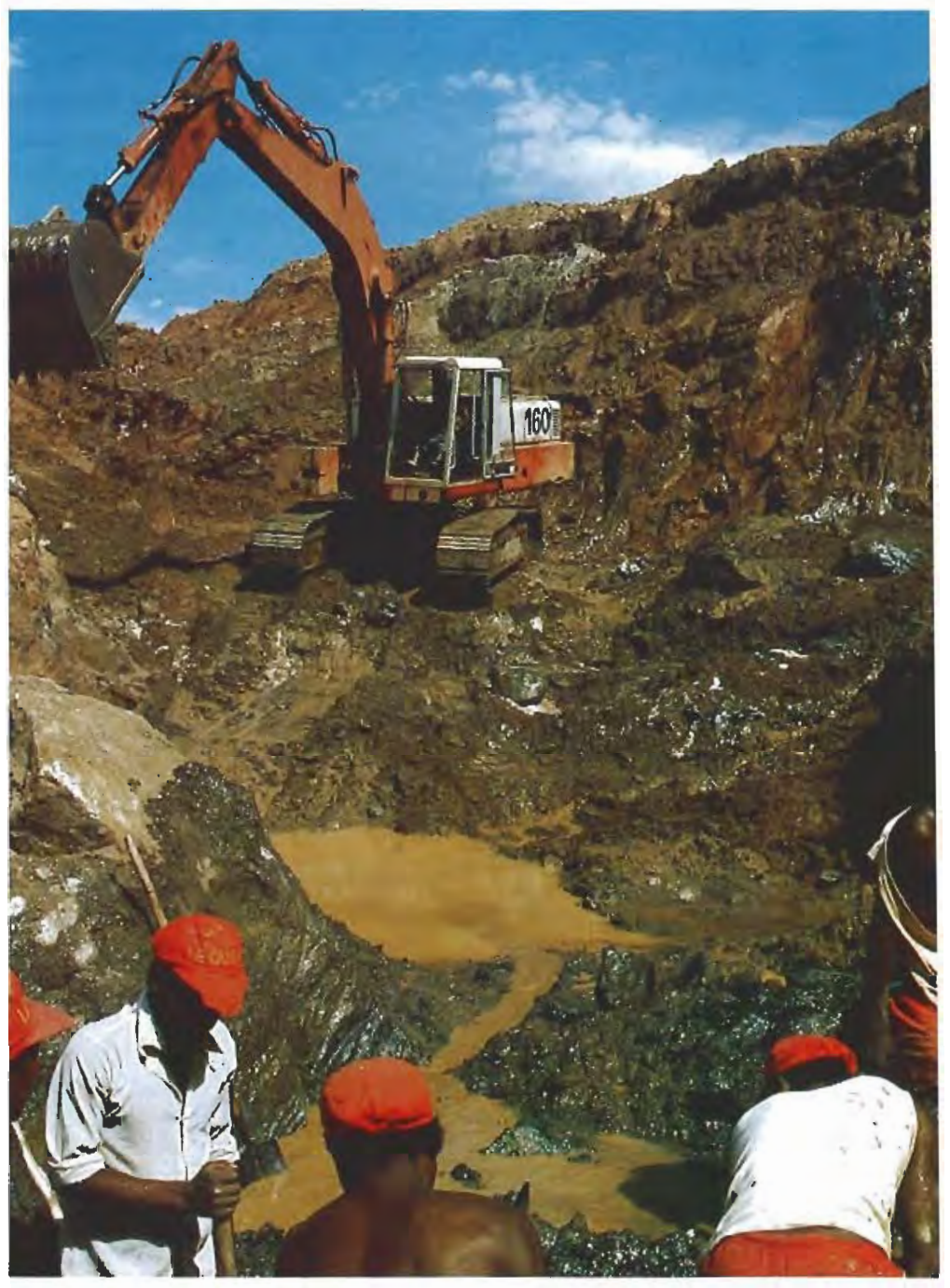


orite, pyrite, and pyrrhotite. Kleyenstüber (1991) also reported the internal features of Madagascar emerald from the same rough that yielded the sample described by Campbell: elongated hollow growth channels with a rectangular outline; a large hexagonal crystal with a distinct yellow-to-green pleochroism (possibly tourmaline or apatite); booklets of mica platelets (phlogopite and, probably, muscovite); negative crystals, usually filled with a liquid and gas; and minute to submicroscopic inclusions of a potassium feldspar (probably microcline) and quartz.

Thomas (1993) did not note any mineral inclusions in stones from Ankadilalana specifically, but only spiral stress fractures and numerous liquidfilled veil- and feather-like inclusions. He did list some mineral inclusions for emeralds from the Mananjary region (but did not indicate the methods by which he identified theml. These include biotite platelets; euhedral transparent crystals of a colorless cubic mineral, possibly rhodizite; and small, wellformed black spinel crystals. Another group of Mananjary emeralds showed oriented "blocky" negative crystals and dense parallel groups of slender acicular negative crystals. In stones from Morafeno, Thomas described "Saturn-like" inclusions comprising a rather large, tabular negative crystal cavity surrounded by a partially healed liquid-and-gas stress halo; "fingerprints"; a few oriented, slender, rod-like inclusions; and small, transparent, cubic crystals (rhodizite?).

\section{MATERIALS AND METHODS}

More than 100 emerald crystals and crystal fragments (see, e.g., figure 7) were examined for this study. They were purchased in the Mananjary mining region by Idar-Oberstein gem dealers /some of whom are involved in the actual mining) and Dr.

Figure 5. Considerable cabochon-quality material, like the 4.88-and 3.42-ct emeralds shown here, has been recovered from deposits in the Mananiary region. Photo by Gerhard Becker.

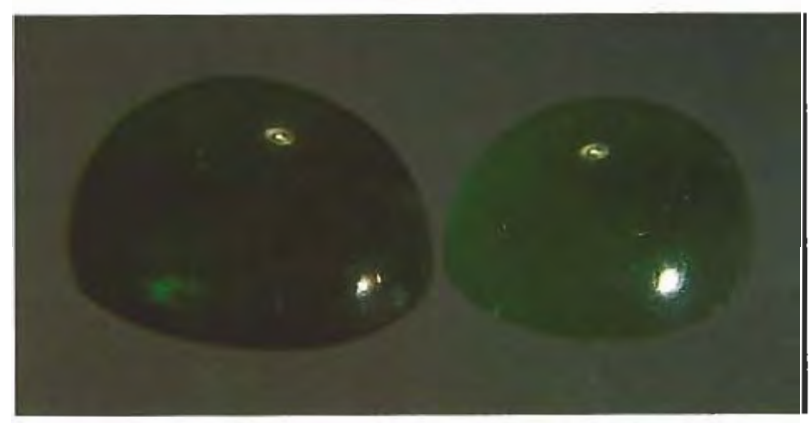

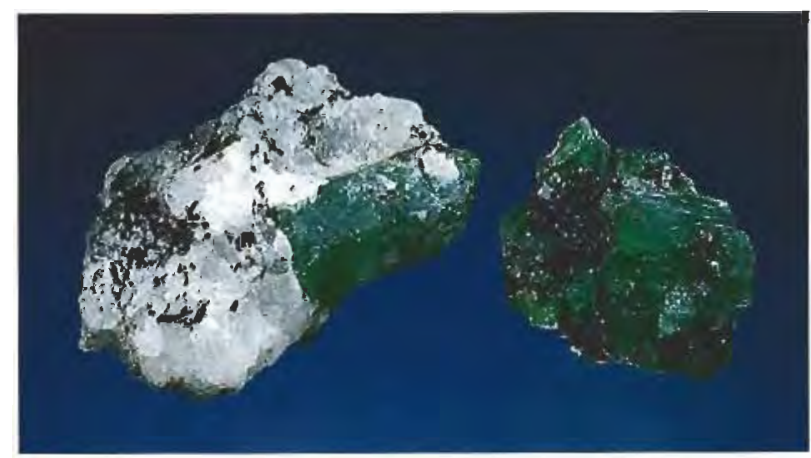

Figure 6. At Mananiary, emeralds are found embedded in a mica or amphibole schist (right) or in quartz (left). The larger specimen measures approximately $35 \times 20 \times 15 \mathrm{~mm}$. Photo (C) GIA and Tino Hammid.

Thomas Eidt. They reportedly came from an area of at least $25 \mathrm{~km}^{2}$ near the town of Morafeno and are representative of the emeralds recovered from the Mananjary deposits. Most of these samples ranged from 0.5 to $3 \mathrm{ct}$.

For this research project, the inclusions were first described and classified using a binocular Schneider immersion microscope with Zeiss optics. Then all of the different types of inclusions were photographed with the samples immersed in benzoic acid. Next, samples with mineral inclusions that appeared to be typical were polished down until the mineral inclusions to be analyzed were exposed at the surface. A Philips XL 30 scanning electron microscope fitted with an EDAX energydispersive X-ray spectrometer (SEM-EDS) was then used for chemical analysis of these inclusions.

Figure 7. These crystals, which average 2-3ct, are representative of the Mananiary samples studied for this report. Photo by Gerhard Becker.

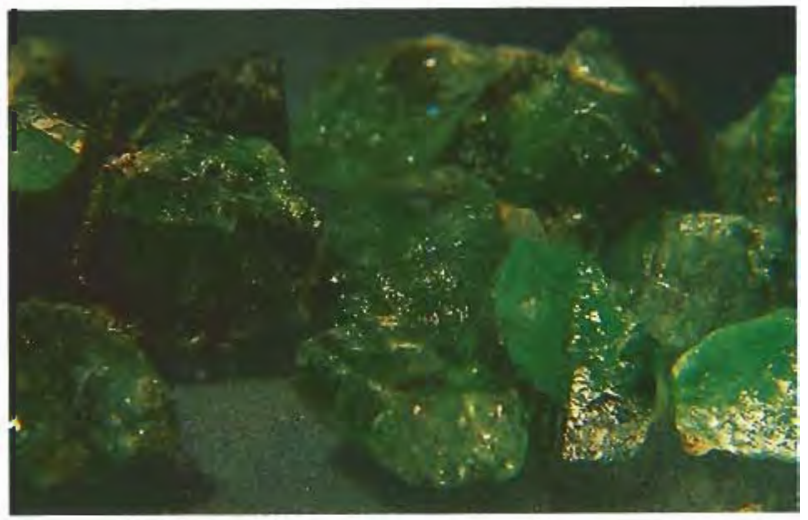


TABLE 1. Mineral inclusions in emeralds from the Mananjary region, Madagascar, and from some other localities. ${ }^{\mathrm{a}}$

\begin{tabular}{|c|c|c|c|c|c|}
\hline Inclusions & $\begin{array}{l}\text { In Mananjary emeralds } \\
\text { as reported by }\end{array}$ & $\begin{array}{l}\text { Also reported in emeralds from } \\
\text { these other localities }\end{array}$ & Inclusions & $\begin{array}{c}\text { In Mananiary emeralds } \\
\text { as reported by }\end{array}$ & $\begin{array}{l}\text { Also reported in emeralds from } \\
\text { these other localities }\end{array}$ \\
\hline $\begin{array}{l}\text { Mica } \\
\text { Biotite/ } \\
\text { Phlogopite }\end{array}$ & $\begin{array}{l}\text { Hänni and Klein (1982) } \\
\text { Campbell (1991) } \\
\text { Kleyenslüber (1991) } \\
\text { Delé-Lasir and Poirotc } \\
\text { Schwarz (this paper) } \\
\text { Thomas (1993) }\end{array}$ & $\begin{array}{l}\text { Most Alrican occurrences } \\
\text { Most occurrences worldwide, e.g; } \\
\text { Austria (Grundmann, 1991; Schwarz, } \\
\quad \text { 1991b) } \\
\text { Australia (Schwarz, 1991a) } \\
\text { Brazil (Hänni et al., 1987; Schwarz et } \\
\text { al., 1988a,b; Schwarz and Eidt, } \\
\text { 1989; Schwarz, 1990; Schwarz et } \\
\text { al., 1990) } \\
\text { Russian Federation (Schwarz, 1991b) }\end{array}$ & $\begin{array}{l}\text { "Carbonates" } \\
\text { Ankerite } \\
\text { Calcite/Fe- } \\
\text { Dolomite } \\
\text { Fluorite } \\
\text { Pyrite }\end{array}$ & $\begin{array}{l}\text { Delé-Lasir and Poirotc } \\
\text { Schwarz (this paper) } \\
\text { Delé-Lasir and Poirotc } \\
\text { Delé-Lasir and Poirotc } \\
\text { Schwarz (this paper) }\end{array}$ & $\begin{array}{l}\text { Austria (Grundmann, 1991) } \\
\text { Brazilo (Schwarz and Eidt, 1989; } \\
\text { Schwarz, 1990; Schwarz et al.,1990) } \\
\text { Colombia' (Gübelin and Koivula. } \\
\text { 1986) } \\
\text { Mozambique (Delé-Lasir and Poirolc) } \\
\text { Pakislan (Henn, 1988) } \\
\text { South Africa (Van Eeden et al., 1939) }\end{array}$ \\
\hline $\begin{array}{l}\text { Apatite } \\
\text { Hemalite }\end{array}$ & $\begin{array}{l}\text { Hänni and Klein (1982) } \\
\text { Delé-Lasir and Poirotc } \\
\text { Hänni and Klein (1982) } \\
\text { Campbell (1991\}d }\end{array}$ & Zambia (Gübelin and Koivula, 1986) & $\begin{array}{l}\text { Pyrrhotite } \\
\text { Rhodiziteb } \\
\text { Soinel }\end{array}$ & $\begin{array}{l}\text { Delé-Lasir and Poirotc } \\
\text { Thomas (1993) } \\
\text { Thomas (1993) }\end{array}$ & \\
\hline $\begin{array}{l}\text { Goethite } \\
\text { Limonited } \\
\text { Quartz }\end{array}$ & $\begin{array}{l}\text { Hänni and Klein (1982) } \\
\text { Campbell (1991)d } \\
\text { Campbell (1991) } \\
\text { Hänni and Klein (1982) }\end{array}$ & & $\begin{array}{l}\text { Amphibole } \\
\text { (actinolite/ } \\
\text { tremolite) }\end{array}$ & Schwarz (this paper) & $\begin{array}{l}\text { Airican localities, including South } \\
\text { Atrica, Zambia, Zimbabwele } \\
\text { Austria (Schwarz, 1991b) } \\
\text { Brazi|b } \\
\text { Russian Federation (Schwarz 1991b) }\end{array}$ \\
\hline & $\begin{array}{l}\text { Kleyenstüber (1991) } \\
\text { Delé-Lasir and Poirolc } \\
\text { Schwarz (this paper) }\end{array}$ & $\begin{array}{l}\text { al., 1983; Bank and Gübelin, 1976; } \\
\text { Delé-Lasir and Poirotc) } \\
\text { Brazil (Hänni et al., 1987; Schwarz et } \\
\text { al., 1988a) }\end{array}$ & Talc & Schwarz (this paper) & $\begin{array}{l}\text { Russian Federation (Schwarz, 1991b) } \\
\text { Brazil (Schwarz, 1990) } \\
\text { Pakistan' } \\
\text { Zimbabwe }^{\text {b }}\end{array}$ \\
\hline $\begin{array}{l}\text { Ilmenite } \\
\text { Tourmaline }\end{array}$ & $\begin{array}{l}\text { Hänni and Klein (1982) } \\
\text { Hänni and Klein (1982) }\end{array}$ & $\begin{array}{l}\text { Austria (Grundmann, 1991) } \\
\text { Brazilb } \\
\text { Russian Federationb) } \\
\text { Zambiab (Koivula, 1992, 1984) }\end{array}$ & Beryl & Schwarz (this paper) & $\begin{array}{l}\text { Brazil (Hänni et al., 1987; Schwarz and } \\
\quad \text { Eidt, 1989; Schwarz, } \\
\text { 1990; Schwarz et al., 1990) } \\
\text { Colombiab } \\
\text { Nigeriab } \\
\text { Pakistan (Delé-Lasir and Poirotc) }\end{array}$ \\
\hline Feldspar & Schwarz (this paper) & $\begin{array}{l}\text { Zimbabwe (Anderson, 1976) } \\
\text { Austria (Schwarz, 1991b) } \\
\text { Brazil (Hänni et al., 1987; Schwarz and } \\
\text { Eidl, 1989; Schwarz et al., 1990) } \\
\text { Colombiab }\end{array}$ & Chlorite & Schwarz (this paper) & $\begin{array}{l}\text { Brazi|b (Schwarz and Eidt, 1989; } \\
\text { Schwarz et al., 1990) } \\
\text { Pakistan (Gübelin, 1989) } \\
\text { Zambiab }^{\text {(bimbabweb }}\end{array}$ \\
\hline & & 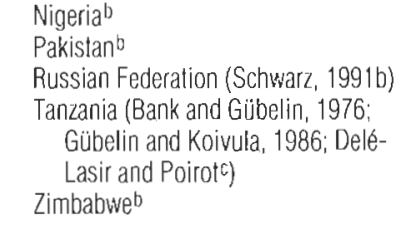 & Molybdenile & Schwarz (this paper) & $\begin{array}{l}\text { Austria (Grundmann, 1991) } \\
\text { Brazil (Hänni ef al., 1987; Schwarz et } \\
\text { al., 1988b; Schwarz and Eidt, } \\
\text { 1989; Schwarz et al., 1990) } \\
\text { Pakistan (Henn, 1988) } \\
\text { South Atrica (Roulet, 1956; Gübelin, } \\
\text { 1973) }\end{array}$ \\
\hline $\begin{array}{l}\text { K-teldspar } \\
\text { Albite } \\
\text { Other } \\
\text { plagioclase }\end{array}$ & $\begin{array}{l}\text { Kleyenstüber (1991) } \\
\text { Schwarz (this paper) } \\
\text { Schwarz (this paper) }\end{array}$ & & Barite & Schwarz (this paper) & $\begin{array}{l}\text { Brazil (Mendes and Svisero, 1988) } \\
\text { Colombia (Mendes and Svisero, } \\
\text { 1988) }\end{array}$ \\
\hline $\begin{array}{l}\text { species or } \\
\text { bobserved } \\
\text { cpersonal } \\
\text { dfdentifical }\end{array}$ & alion, 1991. & s & & & 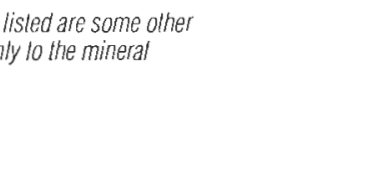 \\
\hline
\end{tabular}

\section{OBSERVATIONS AND RESULTS}

Many different mineral inclusions were identified. Most, but not all, also have been seen in emeralds from other localities in Africa and elsewhere. Table 1 lists the mineral inclusions seen in Mananjary emeralds and the reports on which the Madagascar identifications were based, as well as some other countries that have produced emeralds with similar features (and the corresponding references). Some unusual fluid inclusions have also been seen in the Mananjary stones.

Quartz. About 35\% of the samples contained one or more of the following four types of quartz inclu- 
sions, which were categorized on the basis of their morphology and manner of occurrence:

1. Transparent, colorless, elongated, prismatic crystals oriented with their c-axis parallel to the c-axis of the host emerald, often associated with primary fluid inclusions. These occurred as isolated crystals, irregularly distributed throughout the host crystal, or dispersed over the planes of healing fissures. Some samples contained large numbers of these quartz inclusions in their central regions (figure 8).

2. Angular or somewhat rounded grains, some almost spherical (figure 9). These were less commonly associated with fluid inclusions than was the first type of quartz inclusion. Groups of such grains were concentrated in certain areas.

3. Irregularly rounded crystals, some of which had a badly corroded rough surface.

4. Isolated crystals that were probably daughter crystals of former fluid-filled cavities that were opened during sample preparation (figure 10).

These quartz crystals were often intergrown with other mineral inclusions, including talc, mica,

Figure 8. About a third of the Mananjary emerald crystals examined contained inclusions of quartz. Often, they occur as numerous colorless, transparent, elongated, prismatic crystals oriented in the direction of the c-axis of the host emerald. Many quartz crystals are associated-or intergrown - with growth tubes containing primary fluid inclusions. Immersion, magnified 20x.

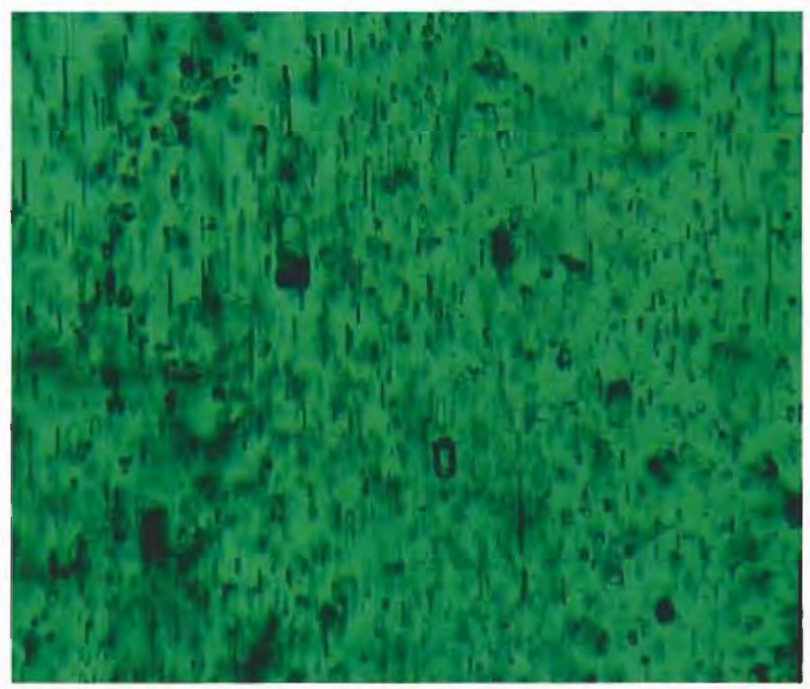

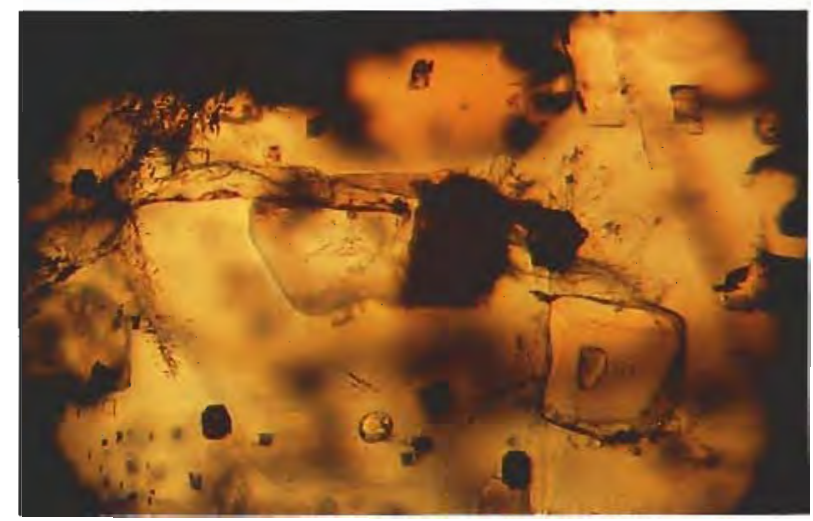

Figure 9. Other quartz inclusions in the

Mananjary emeralds were angular or somewhat rounded. One of the large crystals shown here in a slice cut from one of the samples (the yellow color is from the immersion liquid) is partly covered by a substance that appears black in transmitted light; the other contains what appears to be a small secondary beryl crystal. Note the small, almost spherical quartz crystal toward the bottom of the photomicrograph. Magnified 70x.

amphibole, chlorite, carbonates (figure 11), and beryl. Such aggregates were often accompanied by unhealed tension fissures. In some cases, the quartz inclusions were covered by a substance that appeared black or opaque in transmitted light (again, see figure 9).

Quartz inclusions are mentioned in almost all

Figure 10. This scanning electron micrograph shows a quartz crystal as part of a fluid inclusion in a Mananjary emerald. When the host crystal was polished down and the cavity exposed at the surface, the other-gaseous and liquid--phases of the inclusion were lost. Magnified 500x.

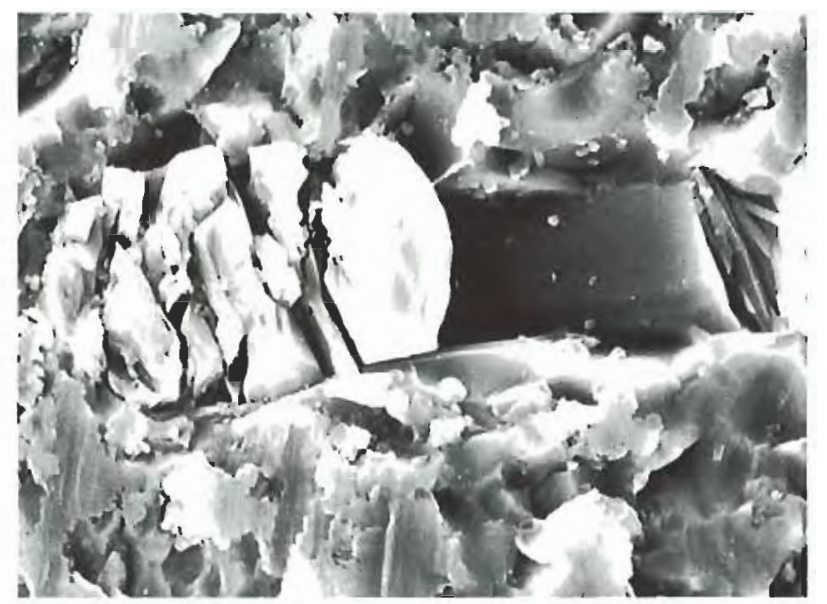


reports on internal features of Madagascar emeralds, and they have been observed in emeralds from virtually all African localities (again, see table 1). Quartz-inclusion types 1 and 2 resemble features observed in many Brazilian emeralds from the Itabira/Nova Era mining region (compare Hänni et al., 1987; Schwarz et al., 1988a). Consequently, quartz inclusions are of little value in determining the locality of the host emerald.

Mica. The most common mineral group observed in the Mananjary emeralds, mica was seen in about half of the samples. In these emeralds, mica occurs mostly as randomly distributed transparent crystals that may appear dark brown in transmitted light. Usually somewhat rounded, they also may have an almost perfect (pseudo-) hexagonal outline (figure 12); they often appear as booklets of thin platelets (figure 13). Chemical analyses showed that most of the micas in the Mananjary emeralds belong to the biotite/phlogopite series /with about 15-20 wt.\% $\mathrm{MgO}, 5-15$ wt.\% FeO, and 10-12 wt. \% $\mathrm{K}_{2} \mathrm{Ol}$, although the $\mathrm{Mg}$ - and $\mathrm{Fe}$-poor species muscovite was alscridentified.

Mica inclusions have been identified in all reports published to date on Madagascar emeralds, and by the author in emeralds from almost all African occurrences (Zambia, Zimbabwe, Tanzania, Mozambique, South Africa, and Egypt). Worldwide, most emerald deposits are related to mica schists. Consequently, biotite/phlogopite micas are the most common mineral inclusions in emeralds. They have been identified, for example, in emeralds

Figure 11. The intergrowth of quartz (black) and carbonate (white) inclusions in Mananjary emeralds is readily apparent in this scanning electron micrograph. Magnified 200x.

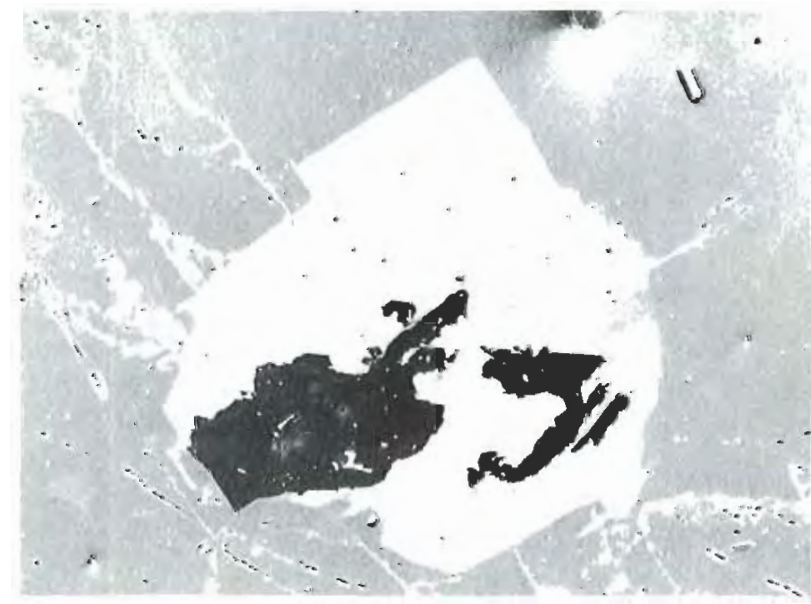

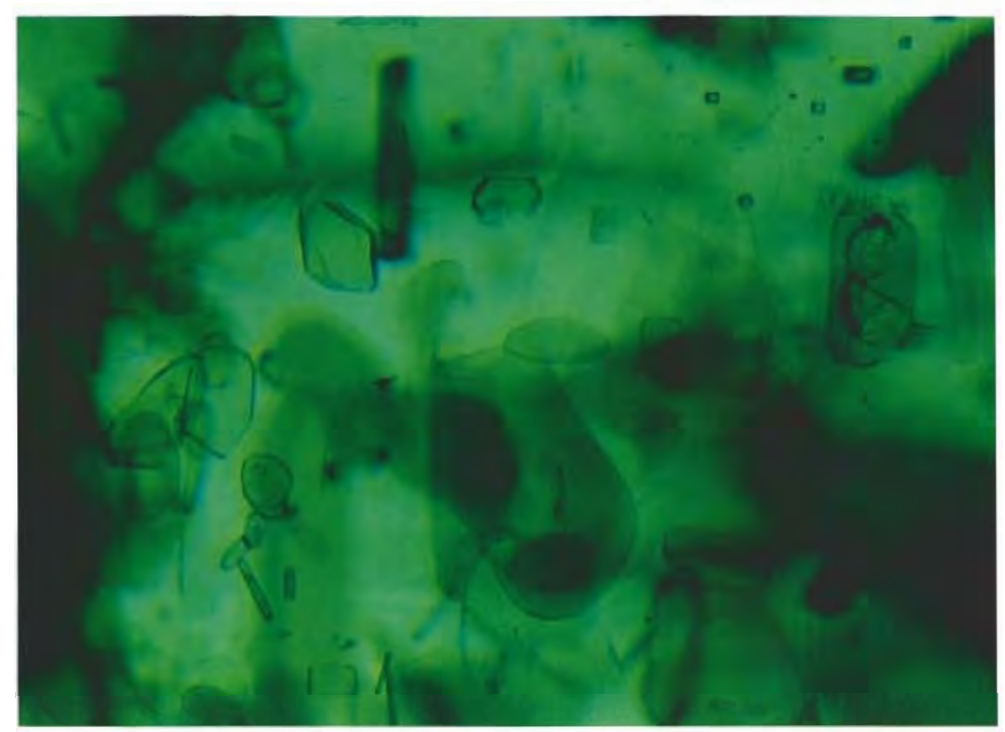

Figure 12. The most common inclusions in the Mananjary emeralds are these transparent, somewhat rounded or pseudo-hexagonal mica crystals (biotite/phlogopite), which are randomly distribut ed (i.e., without crystallographic orientation) in the host ennerald.'Immersion, magnified 50x.

from several localities in Brazil: the Belmont mine (see Hänni et al., 1987) and Capoeirana deposit (Schwarz et al., 1988a), in the state of Minas Gerais; the Fazenda Boa Esperança, Tauá, in Ceará (Schwarz et al., 1988b); the Carnaíba (Schwarz and Eidt, 1989) and Socotó mining areas (Schwarz et al.,

Figure 13. In this Mananjary emerald are found mica booklets (e.g., the upper right); black-

opaque appearing, six-sided molybdenite plates (lower left); and small, roumded fluid inclusions with a very strong relief (like gas bubbles).

Immersion, magnified $35 x$.

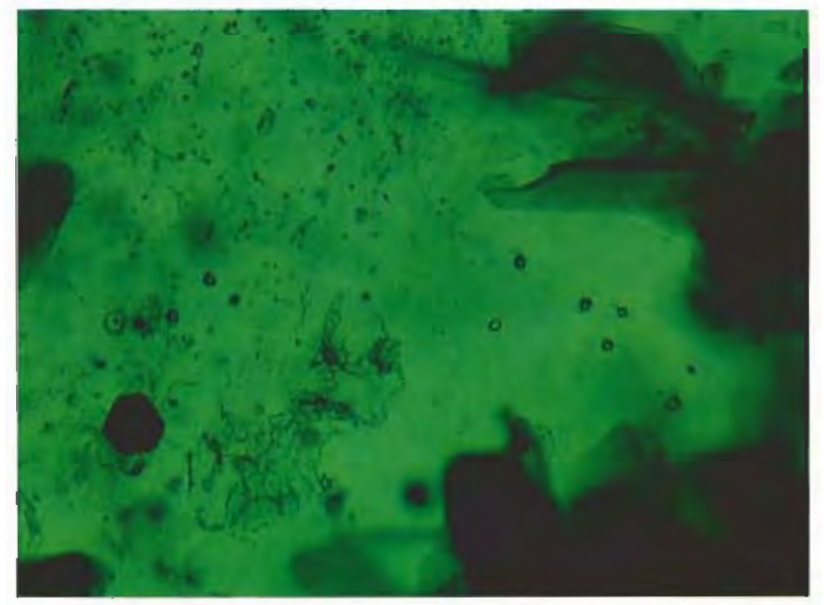




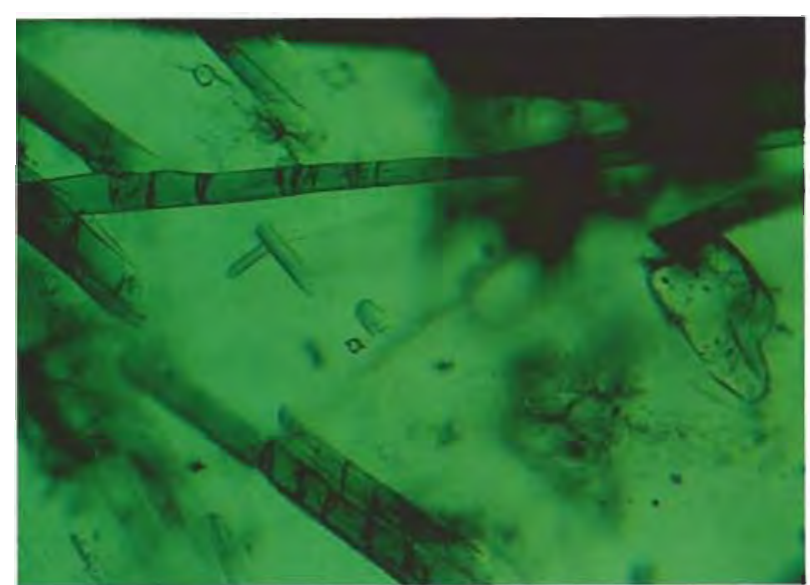

Figure 14. Many of the Mananjary emeralds examined contained long, prismatic, stalk-like, green amphibole (actinolite/tremolite) crystals with a system of fissures that run nearly parallel to the basal face. Note also in this inclusion scene the transparent, colorless, rounded quartz crystal on the far right. Immersion, magnified $50 x$.

1990|, in Bahia; and the Santa Terezinha occurrence, in Goiás (Schwarz, 1990). Mica inclusions have also been described in emeralds from the Poona region and from Menzies in Western Australia (Schwarz, 199la), from the Ural Mountains in the Russian Federation (Schwarz, 1991b), and from the Habach Valley (Habachtall in Austria (Grundmann, 1991; Schwarz, 1991b).

Amphiboles. Until this study, minerals of the amphibole group had not been described as inclusions in Madagascar emeralds (see, e.g., Thomas, 1993). The author has seen them in emeralds from other African localities /the Sandawana/Machingwe mining area in Zimbabwe, the Ndola Rural district in Zambia, and the Leydsdorp district in South Africal, as well as the Carnaíba, Socotó, and Fazenda Boa Esperança mining areas in Brazil, among others. Although mica schists are the most common host rocks for emeralds, often these schists grade into amphibole-bearing or amphibole schists. This explains why amphiboles (mostly of the actinolite/tremolite series) are frequent inclusions in many emeralds and are sometimes the dominant inclusion mineral (as, for example, in emeralds from the Zeus claims in the Sandawana region of Zimbabwe).

Amphibole crystals were seen in about $20 \%$ of the emeralds in this study. The amphibole crystals observed belong to the actinolite/tremolite series, with $\mathrm{FeO}$ and $\mathrm{MgO}$ each about 10-15 wt.\%. The sum $\left(\mathrm{FeO}_{\text {tot }}+\mathrm{MgO}\right)$ in different crystals was found to be constant at about $26 \mathrm{wt} . \%$. The actinolite/ tremolite crystals are green, with a long, prismatic, stalky habit. Often they show systems of nearly parallel planes that are slightly inclined with respect to the main axis of the crystals (figure 14). This results in the bamboo-like appearance typical of actinolite/tremolite inclusions in emeralds from several other occurrences. The random distribution of these crystals and the fact that they are often broken at their extremities suggests that they are protogenetic, that is, that they formed before the host emerald.

The relative distribution of mica and amphibole crystals in the Mananjary emeralds is very irregular. Some emeralds contain many mica crystals and are practically free of amphiboles; others contain numerous amphibole crystals but practically no mica; and many contain amphibole and mica in almost equal quantities. This reflects the varying composition of the host rock in which the emeralds formed: a mica schist, an actinolite/tremolite schist, or a combination of both. It is likely that amphiboles were not reported in prior articles on inclusions in Mananjary emeralds because the samples studied were taken only from mica schists and not from amphibole schists.

Carbonates. About $15 \%$ of the samples contained carbonate inclusions, which are also relatively rare

Figure 15. Rhombohedral carbonate crystals were seen in many of the Mananjary emeralds. Although the crystal is actually colorless, it may appear brown in transmitted light because of corrosion at its surface. Immersion, magnified $70 \times$.

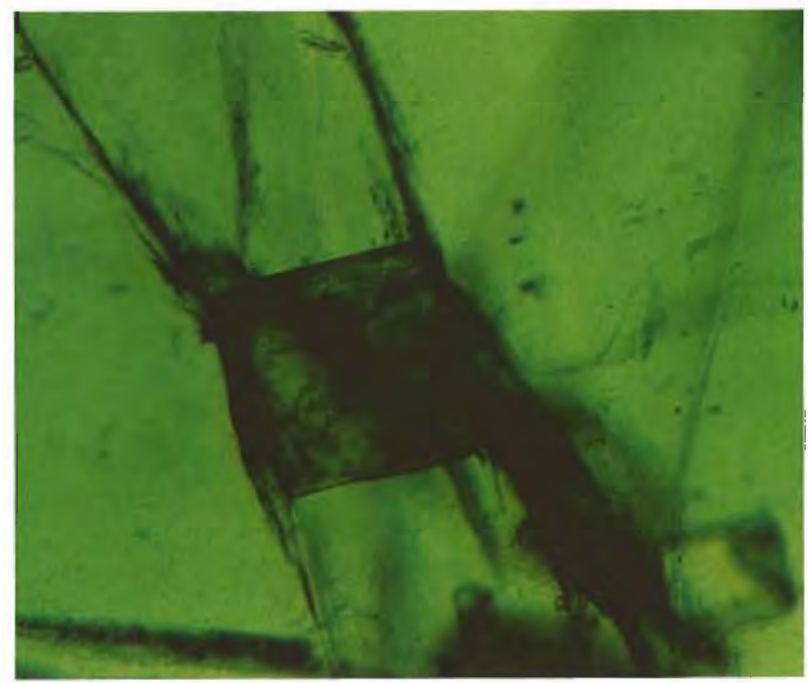


in emeralds from other African localities. M. L. Delé-Lasir and J. P. Poirot (pers. comm., 1991) have identified carbonates in emeralds from the Transvaal in South Africa (as did Roulet, 1956), as well as from Zambia (dolomite, calcite) and Sandawana (dolomite, calcite).

Although some of the Mananjary-emerald carbonate inclusions were relatively well-developed rhombohedral crystals (figure 15), most were irregular or rounded grains; in general, they appeared transparent and colorless. The rare prismatic carbonate crystals observed usually appeared black or opaque in transmitted light because they contained numerous minute inclusions. Surface corrosion made some carbonate crystals appear slightly brown in transmitted light.

The carbonate inclusions are usually calcite crystals with small amounts $(<1-2$ wt.\%) of manganese and/or iron. However, chemical analyses also identified Fe-dolomite and a calcite containing relatively high $\mathrm{FeO}$ and small amounts $(<1 \%)$ of magnesium and manganese. Frequently, the carbonate crystals were intergrown with other mineral species (most commonly quartz and talc; again, see figure 11).

Feldspar. Feldspar crystals were identified in about $5 \%$ of the Mananjary emerald crystals. Surface corrosion and the presence of minute inclusions (of quartz, among other minerals) gave some of these typically transparent and colorless crystals a somewhat darker (sometimes brown) appearance in transmitted light. They were usually irregular in shape and often very rounded. The feldspars analyzed varied from almost pure albite (Na-feldspar) to a plagioclase containing about $5 \mathrm{wt} . \% \mathrm{Na}_{2} \mathrm{O}$ and 6-7 wt.\% CaO. Sometimes, the feldspars were intergrown with quartz or mica. Kleyenstüber (1991) described a K-feldspar inclusion in a Madagascar emerald.

As table 1 indicates, feldspar inclusions also have been observed (by the author and others) in emeralds from Zimbabwe and Nigeria, as well as from Tanzania. Representatives of this mineral group are also known in emeralds from other occurrences, such as Colombia and the Swat region of Pakistan; the Belmont mine, Carnaíba, and Socotó, in Brazil; the Ural Mountains of the Russian Federation; and the Habach Valley of Austria.

Talc. Before this study, talc had not been reported as an inclusion in Madagascar emeralds. Talc inclusions were identified in about $20 \%$ of the samples.

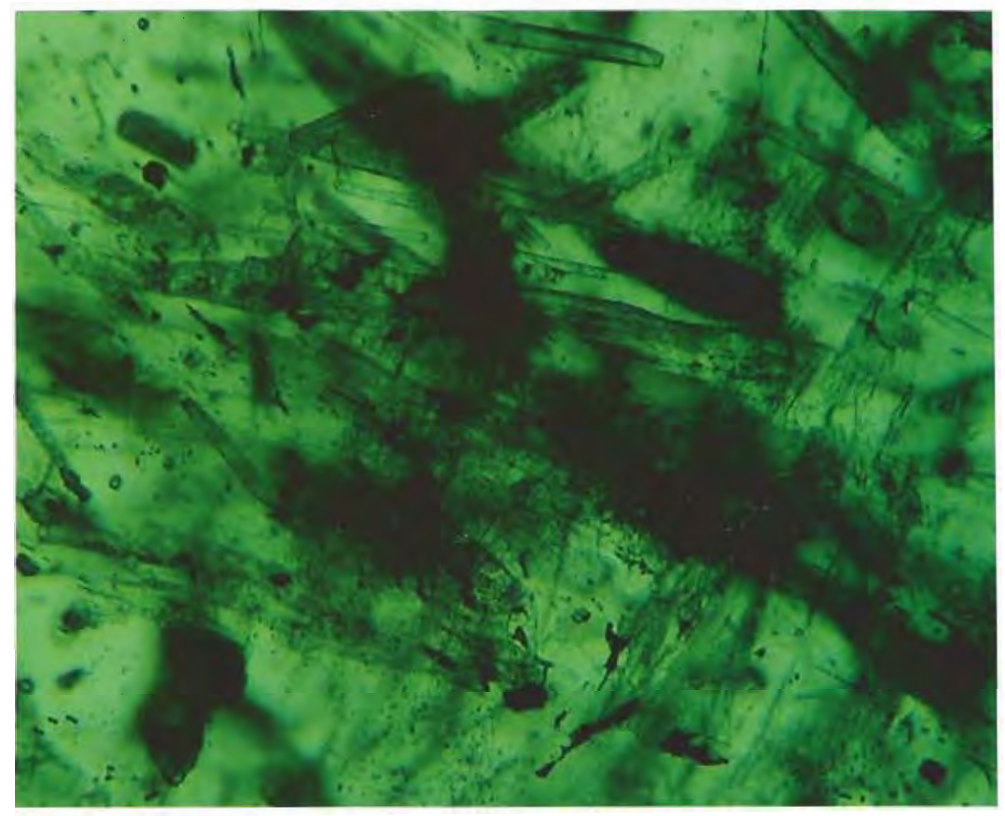

Figure 16. These fibrous aggregates are representative of the talc inclusions seen in Mananjary emeralds. Magnified 50x.

Normally light green, some were more brown. Chemical analysis revealed that the differences in color are related to iron substituting for magnesium in the crystal lattice. The FeO concentration in the analyzed crystals varied between 7 and $12 \mathrm{wt} . \%$. Talc was observed in four different forms: (1) uncommonly, as fibrous aggregates, sometimes with a sheaf-like aspect (figure 16); (2) as irregularshaped scales dispersed over fracture planes (possibly introduced in conjunction with an epigenetic filling process); $|3|$ as pseudohexagonal transparent green platelets; and (4) intergrown with other inclusion minerals (e.g., quartz, pyrite).

The Sandawana/Machingwe (Zimbabwe) region is the only other place in Africa where talc crystals have been found in emeralds-and then only rarely. Therefore, the presence of talc (especially in its fibrous or sheaf-like form) may be useful in separating Mananjary emeralds from those from other African localities. However, the author has found that talc is one of the most common mineral inclusions in emeralds from the talc-carbonate schists of Santa Terezinha de Goiás, Brazil, and from the Swat region, Pakistan (see table 1).

Beryl. Inclusions of beryl typically occur either as colorless, irregular, strongly corroded crystals or as well-developed, heavily included prisms that appear white in darkfield illumination. In addition, sonre 


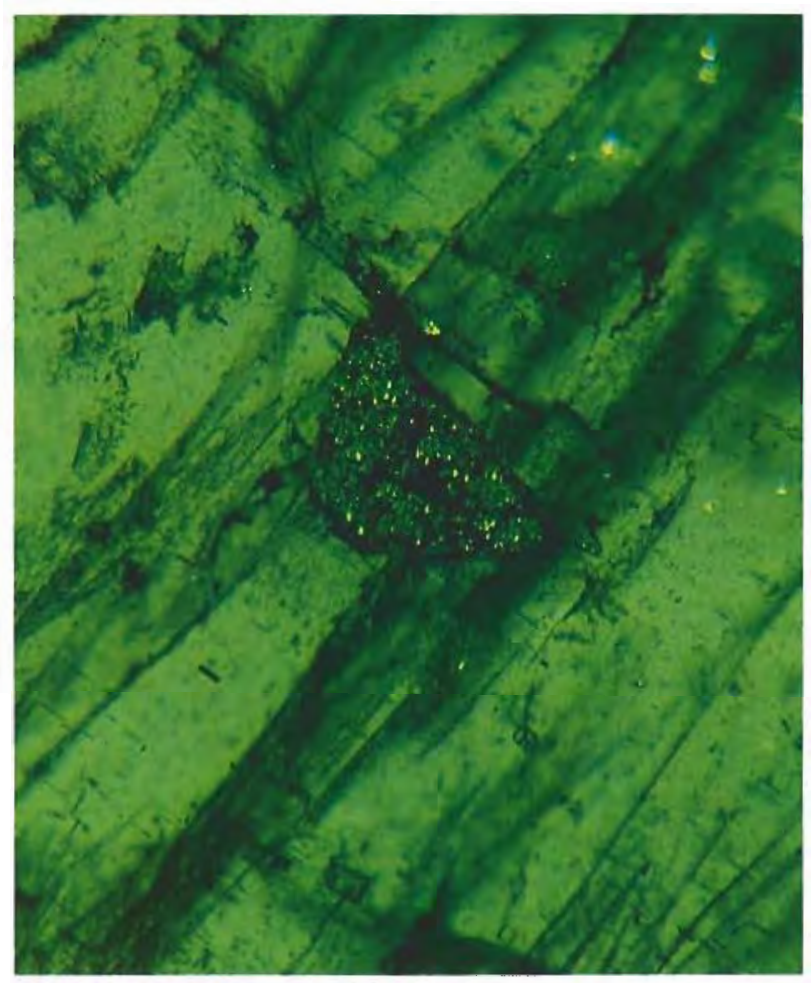

Figure 17. In reflected light, this pyrite grain in a Mananiary emerald shows the yellow color and metallic luster typical of this mineral. Immersion, magnified $50 x$.

beryl was observed as rounded grains in quartz inclusions (again, see figure 9), which indicates that at least two beryl "generations" (with different features) occurred in the area of the emerald mineralizations. Beryl and/or emerald crystals have been identified by the author and others as inclusions in emeralds from several occurrences (e.g., Colombia, Nigeria, Pakistan, and various localities in Brazil), so their presence is of little diagnostic value when determining the origin of an emerald.

Chlorite. Chlorite was observed in only a few samples, as small grains or platelets intergrown with quartz and/or mica. Although not previously reported in Madagascar emeralds, chlorite has been seen by the author in emeralds from Zambia, Zimbabwe, and the Itabira/Nova Era region in Minas Gerais, Brazil. Chlorite has also been seen in material from Pakistan and elsewhere in Brazil (Carnaíba and Socotó; see table 1).

Molybdenite. Identified in less than $5 \%$ of the Mananjary emeralds, molybdenite crystals occur as gray to silver platelets with a typical metallic lus- ter. They may be slightly rounded or show a welldeveloped hexagonal outline (again, see figure 13).

Molybdenite is known as an inclusion in emeralds from many areas, such as the Transvaal in South Africa, various Brazilian deposits, the Habach Valley of Austria, and the Swat Valley of Pakistan (again, see table 1). Molybdenite has not been described before in emeralds from Madagascar.

Pyrite. Observed in less than 5\% of the Mananjary samples, pyrite-as determined by X-ray diffraction analysis of a representative iron sulfide inclusionappeared a typical metallic yellow under reflected light (figure 17). Most of the pyrite crystals were well developed. Chemical analyses revealed about 2 wt. \% NiO and small amounts $(<0.5$ wt. \%) $\mathrm{ZnO}$.

M. L. Delé-Lasir and J. P. Poirot (pers. comm., 1991) have identified pyrite in emeralds from Mozambique as well as from Madagascar. Pyrite has been seen frequently by the author in emeralds from different types of occurrences, including Colombia, as well as the Santa Terezinha, Carnaíba, and Socotó deposits in Brazil. Pyrite has also been reported in emeralds from the Transvalal in South Africa, the Habach Valley of Austria, and the Swat Valley of Pakistan (see table 1).

Barite. Barite was observed in only two samples, as very small, colorless, transparent grains of irregular shape. Apparently a very rare inclusion in emerald, it has been reported in emeralds from only two other localities-Colombia and Santa Terezinha de Goiás, Brazil (Mendes and Svisero, 1988). It has not been reported for Madagascar emeralds before.

Tourmaline. Tourmaline was observed in less than $5 \%$ of the Mananjary emeralds. Those crystals seen were typical trigonal prisms, which chemical analysis showed to be members of the dravite-schorl series. Tourmaline inclusions, although by no means common in emerald, have been identified previously in Madagascar emeralds (Hänni and Klein, 1982) and by the author and others in emeralds from widely different occurrences elsewhere: Zambia and Zimbabwe in Africa, the Ural Mountains of the Russian Federation, Carnaíba and Socotó in Brazil, and the Habach Valley in Austria (see table 1).

Fluid Inclusions. One or more of the following types of fluid inclusions were observed in most of the Mananjary samples: 
1. Numerous minute fluid inclusions /some associated with quartz-again, see figure 8and others with an unidentified material) contained in healed to partly healed fissures.

2. Larger fluid or mineral inclusions accompanied by black-appearing spheres-actually clusters of numerous minute fluid inclusions (figure 18).

3. Primary fluid inclusions, often associated with quartz crystals. These inclusions were typically elongated-that is, within growth tubesin a direction parallel to the c-axis of the host emerald (again, see figure 8). Most had welldeveloped rectangular or square outlines (negative crystals; figure 19); others were rounded and strongly resembled gas bubbles. Most of the fillings were two-phase (liquid and gas), but three-phase inclusions were also observed. These fluid inclusions may show unusually strong relief and, in transmitted light, often are so dark as to appear opaque.

When large numbers of primary fluid inclusions occur in fine, elongated cavities (figure 8), they are responsible for the so-called rain effect that gives a silk-like sheen to cabochon-cut emeralds. In some cases, they can even generate chatoyancy.

The fluid inclusions observed in the study samples resemble those in emeralds from the Ndola Rural district of Zambia, and from the Itabira/Nova Era mining region of Minas Gerais, Brazil (Belmont and Capoeirana; compare Hänni et al,, 1987, and Schwarz et al., 1988a). However, in the Mananjary samples they do not display the impressive variety of their Brazilian counterparts.

Other Microscopic Features. Other internal features observed in the Mananjary emeralds include:

- Color zoning: normally a light core and a dark outer zone

- Growth striae parallel to the prism faces

- Concentrations of inclusions in certain areas of the host crystal (e.g., a central zone with numerous minute quartz crystals)

- Systems of essentially parallel fractures that are only partly healed

- Various types of fissures: delicate healed fissures with small fluid inclusions (often almost flat or slightly wavy, almost parallel to one another, and sometimes oriented parallel to the basal pinacoid of the host emerald); unoriented, unhealed fissures (partly filled with an unidentified material); and unoriented, healed fissures with numerous minute "particles" (probably minute fluid inclusions)

\section{DISCUSSION AND CONCLUSIONS}

Although precise production figures for the emerald occurrences in the Mananjary region are not available, from the size of some of the mechanized operations it can be concluded that many thousands of carats have been mined. In addition, geologic conditions appear to favor the discovery of larger mineralization sites (Th. Eidt, pers, comm., 1993). Because the physical and chemical properties of Mananjary emeralds fall within the ranges for emeralds from most other localities, the emeralds of this region are best identified by their internal features.

Mananjary emeralds come from a geologic environment that is characterized by the association of different metamorphic schists (principally biotite/phlogopite schists and subordinately amphibole-bearing or amphibole schists) and pegmatite veins (that is, a "schist-type deposit," where pegmatites or pegmatoid veins are the primary source of the element beryllium). Thus, their inclusion features are very similar to those in most emeralds from other schist-type deposits (e.g., quartz, platelets of biotite/phlogopite mica, rods or needles of actinolite/tremolite, platelets or grains of chlorite, and feldspar crystals). These types of inclusions may occur, for example, in emeralds from Zambia

Figure 18. Spherical clusters of numerous fluid inclusions that appeared black in transmitted light were relatively common in the Mananjary emeralds but have not been reported in emeralds from many other localities. Immersion, magnified $50 x$.

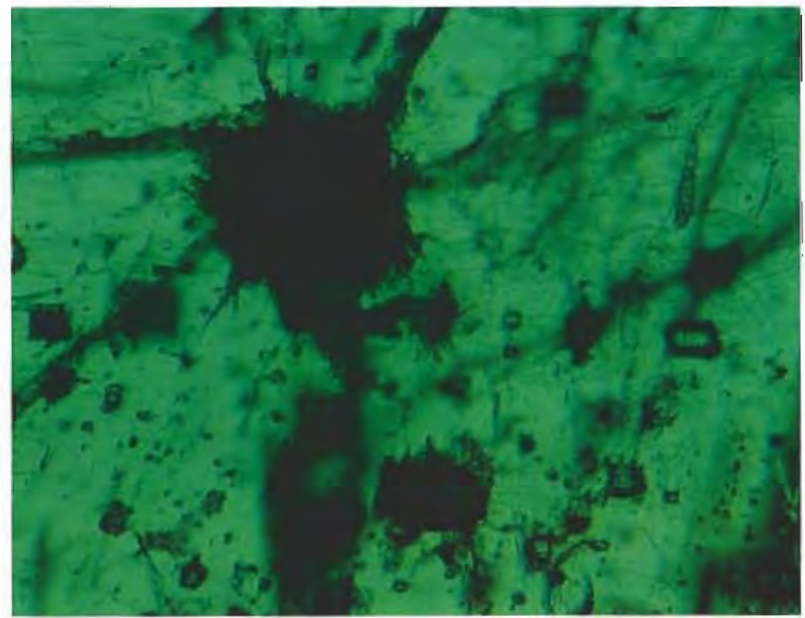


(Ndola Rural district), Zimbabwe (Sandawana/ Machingwe mining region), South Africa (Leyds dorp/Transvaal), and Brazil (e.g., Bahia and Minas Gerais). Other mineral inclusions-such as apatite, hematite, ilmenite, tourmaline, pyrite, or molybdenite-also can be seen in emeralds from other localities and different formation environments. However, they are so rare that they are of little diagnostic value.

Even with all of these restrictions, most Madagascar emeralds can be separated from those from other African localities. What is most characteristic is the association of certain mineral inclusions (especially talc, carbonates, amphiboles, and quartz) with specific types of fluid inclusions, such as: fluid inclusions with quartz crystals, in healing fissures; fluid inclusions in large numbers, forming spherical black clusters; and primary fluid inclusions that show very strong relief and appear almost opaque, or are rounded and resemble gas bubbles. Of the other African localities, only Zambian emeralds have fluid inclusions that are similar to the primary fluid inclusions, with well-developed rectangular or square outlines (negative crystals), seen in the Madagascar stones.

As previously mentioned, the fluid inclusions in emeralds from the Itabira/Nova Era region in Minas Gerais, Brazil (Belmont and Capoeirana mining fields), are similar to those observed in the Madagascar samples. Separating emeralds from these two sites could be very difficult. The presence of talc-especially when it appears in a fibrous or sheaf-like form-is a good diagnostic feature for Mananjary emeralds. So far it has been observed only very rarely in emeralds from one other African locality (the Sandawana/Machingwe mining area of Zimbabwe). Although talc is seen in

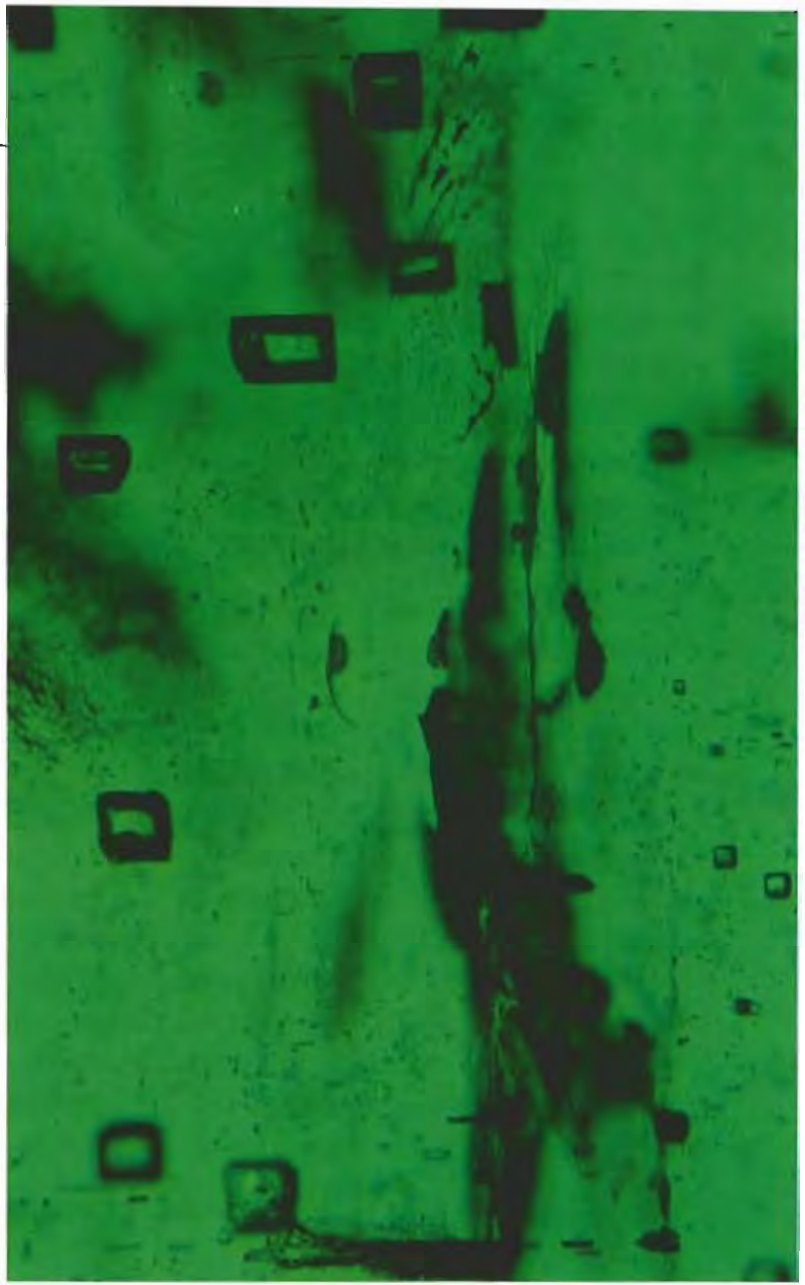

Figure 19. Fluid-filled negative crystals (usually with a gas phase as well) were common in the Mananiary emeralds examined. Note the welldeveloped rectangular or square outlines. Immersion, magnified $50 x$.

emeralds from other localities (e.g., Santa Terezinha de Goiás, Brazil, and the Swat region of Pakistan) the other internal features of these emeralds are so different that they are easily separated from Mananjary stones.

\section{REFERENCES}

Anderson S.A. (1976) A note on the occurrence of enerald at Mayfield Farm, Fort Victoria, Rhodesia, Journal of Gemmology, Vol. 15, No. 2, pp. 80-82.

Bank H., Gübelin E. (1976) Das Smaragd-Alexandritvorkommen von Lake Manyara/Tansania. Zeitschrift der Deutschen Gemmologischen Gesellschaft, Vol. 25, No. 3, pp. 130-147.

Campbell C.C. (1991) A report on one of a number of emeralds from Madagascar. South African Gemmologist, Vol. 5, No. 1, pp. $8-15$.

Chikayama A. (1989) Gem localities in Madagascar. In Abstracts of the 22nd International Gemmological Conference (ICG), Como/Milano, Italy,

Graziani G., Gübelin E., Lucchesi S. (1983) The genesis of an emerald from the Kitwe district, Zambia. Nenes Jahrbuch für Mineralogie, Monatshefte, Vol. 12, No. 4, pp. 175-186.
Grundmann G. (1991) Smaragd. Extra-LAPIS No. 1. Christian Weise Verlag, Munich, Germany

Gübelin E. (1973) Internal World of Gemstones. ABC Edition, Zurich.

Gübelin E. (1989) Gemological characteristics of Pakistani emeralds. In A. H. Kazmi and L. W. Snce, Eds., Emeralds of Pakistan: Geology, Gemology, and Genesis, Van Nostrand Rcinhold, New York, pp. 75-91.

Gübclin E., Koivula J.I. (1986) Photoatlas of Inclusions in Gemstones. ABC Edition, Zurich.

Hänni H.A., Klein H.H. (1982) Ein Smaragdvorkommen in Madagaskar. Zeitschrift der Deutschen Gemmologischen Gesellschaft, Vol. 31, No. 1/2, pp. 71-77.

Hänni H.A., Schwarz D., Fischer M. (1987) The emeralds of the Belmont Mine, Minas Gerais, Brazil. Joumal of Gemmology, 
Vol. 20, No. $7 / 8$, pp. 446-456

Henn U. (1988) Untersuchmgen an Smaragden aus dem Swat Tal, Pakistan. Zeitschrift der Deutschen Gemmologischen Gesellschaft, Vol. 37, No. 3/4, pp. 121-127

Kleyenstüber A. (1991) Observation of inclusions in a Madagascar emerald and their possible implications. South African Gemmologist, Vol. 5, No. 2, pp. 4-9.

Koivula J.l. (1982) Tourmaline as an inclusion in Zambian emeralds. Gems e) Gemology, Vol. 18, No. 4, pp. 225-227.

Koivula J.I. (1984) Mineral inclusions in Zambian emeralds. Australian Gemmologist, Vol. 15, No. 7, pp. 235-239.

Lacroix A. (1922) Minéralogie de Madagascar. Augustin Challamel, Paris.

Levat M.D. (1912) Richesses Minérales de Madagascar. Dunod \& Pinat, Paris

Mendes J.C., Svisero D.P. (1988) As inclusōes cristalinas e fluidas da esmeralda de Santa Terezinha de Goiás e seu significado geológico. Anais do XXXV Congresso Brasileiro de Geologia, Belém, Pará, Vol. 1, pp. 398-4ll.

Roulet B. (1956) Métodos para determinação da procedencia de esmeraldas. Gemologia (Sao Paulo), No. 5, pp. 33-40.

Schwarz D. (1987) Esmeraldas. Inuprensa Universitária, Escola de Minas, Universidade Federal de Ouro Preto, Minas Gerais Brazil.

Schwarz D., Bank H., Henn U. (1988a) Neues Smaragd vorkommen in Brasilien entdeckt: Capoeirana bei Nova Era Minas Gerais. Zeitschrift der Deutschen Gemmologischen Gesellschaft, Vol. 37, No. 3/4, pp. 146-147.

Schwarz D., Hänni H.A., Martin F.L., Fischer M. (1988b) The emeralds of Fazenda Boa Espcrança, Tauá, Ceará, Brazil
Occurrence and properties, Journal of Gemmology, Vol. 21, No. 1, pp. 168-177.

Schwarz D., Eidt Th. (1989) The Brazilian emeralds and their occurrences: Carnaíba, Bahia. Journal of Gemmology, Vol. 21, No. 8 , pp. 474-486.

Schwarz D., Eidt Th., Couto P.A. (1990) The Brazilian emeralds and their occurrences: Socotó, Bahia. Journal of Gemmology, Vol. 22, No. 3, pp. 147-163.

Schwarz D. (1990) Die brasilianischen Smaragde und ihre Vorkommen: Santa Terezinha de Goiás/GO. Zeitschrift der Deutschen Gemmologischen Gesellschaft, Vol. 39, No. 1, pp. $13-44$.

Schwarz D. (1991a) Die chemischen Eigenschaften der Smaragde II, Australien und Norwegen. Zeitschrift der Deutschen Gemmologischen Gesellschaft, Vol. 40, No. 1, pp. 39-66.

Schwarz D. (1991b) Die chemischen Eigenschaften der Smaragde III. Habachtal/Osterreich und Uralgebirge/UdSSR. Zeitschrift der Deutschen Gemmologischen Gesellschaft, Vol. 40, No. 2/3, pp. $103-143$.

Schwarz D, Henn U. (1992) Emeralds from Madagascar. Journal of Gemmology, Vol. 23, No. 3, pp. 140-149.

Sinkankas J. (1981) Emerald and Other Bery/s. Chilton Book Co., Radnor, PA.

Thomas A. (1993) The emerald mines of Madagascar. South African Gemmologist, Vol. 7, No. 3, pp. 3-11.

Van Eeden O.R., Partridge F.C., Kent L.E., Brandt J.W. (1939) The Mineral Deposits of the Murchison Range, East of Leydsdorp. Geological Survey of South Africa, Memoir No. 36, Pretoria.

\section{The ultimate authority on diamonds and the diamond industry is now available for consultation. Presenting THE GIA DIAMOND DiCTIONARY, 3rd EDITION \\ Completely revised and updated $\diamond$ More full color photos, drawings and charts $\diamond 100+$ newly commissioned maps $\diamond$ More facet diagrams $\diamond$ \\ More international in scope}

The GIA Diamond Dictionary, 3rd Edition, contains the knowledge and

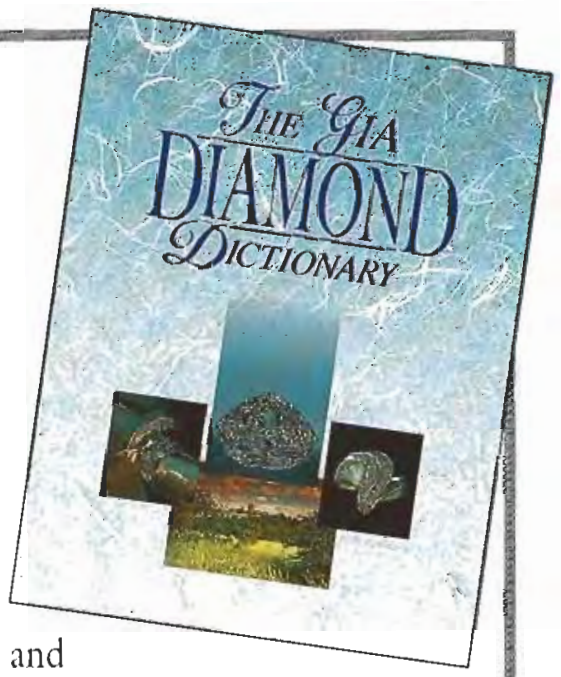
expertise of an unprecedented team of industry leaders - gemologists, cutters, designers, bench jewelers, historians, geologists, physicists, and chemists from the South African grasslands to the Australian outback. It's the most detailed examination of the vast, complex and diverse world of diamonds ever published. No jewelry professional and/or student of gemology can afford to be without it.

To obtain your copy of The GIA Diamond Dictionary, 3rd Edition, for only $\$ 99.50$ (plus tax and shipping), call today toll-free:

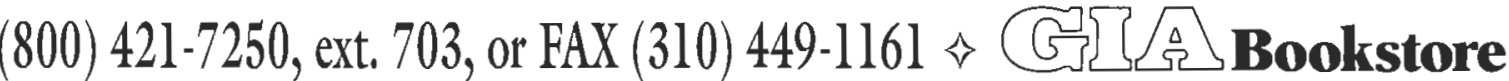

